\title{
CNC MEGMUNKÁLÓBERENDEZÉS ELMÉLETI MELEGEDÉSVIZSGÁLATA
}

\author{
Kundrát Tamás \\ fejlesztömérnök, Robert Bosch Power Tool Kft. \\ 3526 Miskolc, Robert Bosch Park 1., e-mail: kundrattamas@gmail.com \\ Szilágyi Attila \\ egyetemi docens, Miskolci Egyetem, Szerszámgépészeti és Mechatronikai Intézet, \\ Szerszámgépek Intézeti Tanszéke \\ 3515 Miskolc, Miskolc-Egyetemváros, e-mail: szilagyi.attila@uni-miskolc.hu
}

\begin{abstract}
Absztrakt
Cikkünkben egy 5-tengelyes CNC megmunkáló berendezés végeselem-módszerrel történö elméleti vizsgálatát mutatjuk be. Egy megmunkálóberendezés tervezésének korai fázisában a leendö berendezés melegedési tulajdonságainak ismerete nagyon fontos, hiszen a megmunkálás jellegénél fogva a marógépek megnövelt hőhatásnak vannak kitéve. Ennek során idöben változó hőhatás éri a megmunkálási környezetet, amely höfeszültségeket ébreszt a szerszám mellett a berendezésben is, igy hatással van a megmunkált darab méretpontosságára. A melegedés, közvetlen káros hatásai mellett, a megmunkálóberendezés hosszútávú viselkedésre is hatással van, tehát a melegedés folyamatának ismeretében lehetöségünk van optimális viselkedésü berendezés megtervezésére, illetve optimális körülmények közötti müködtetésére.
\end{abstract}

Kulcsszavak: melegedés szimuláció, VEM-vizsgálat, hömérsékletmezö

\section{Abstract}

This article concerns a thermal simulation of a 5-axis CNC milling machine by finite element method. At the early stage of a machine designing process, the analysis of thermal conditions is really important, because milling machines are exposed to heat effects. The result of it is a nonstationary temperature field, which can influence accuracy of positioning and it can generate thermal stress in the structure of machines. Besides harmful heat effects can decrease geometry accuracy of manufactured product, but making thermal analysis quality and lifecycle of products can be higher and planning time can be reduced.

Keywords: thermal simulation, FEM-analysis, temperature field

\section{Bevezetés}

A hő az energia egyik megjelenési formája, amely különböző hőmérsékletű rendszerek közötti áramlás formájában terjed. Egy megmunkálóberendezés hőforrásai lényegében energiaforrások, amelyekből hőenergia áramolhat a berendezés belsejébe. A hőenergia terjedésének három lehetséges módját tartjuk számon: hővezetés, hőátadás és hősugárzás. Hővezetés során a hőenergia a test részecskéin keresztül terjed, hỏátadás során a részecskék makroszkopikus távolságon át terjesztik a hőt, míg sugárzás során a hőenergia elektromágneses energia formájában terjed. 


\section{A hőmérsékletmező feltárása}

Ebben a fejezetben a hőmérsékleteloszlás kialakulásának elméleti hátterét mutatjuk be röviden. Ez elapján ítélhetjük meg egy megmunkálóberendezésen jelenlévő hőmérsékletmező kialakulását. A hömérsékletmező általában a hely- és időkoordináták függvényében adható meg, ahogyan ezt az alábbi

$$
T=T(x, y, z, t) .
$$

formula is rögzíti [1]. (1) alakban adódik a vizsgálatba vont berendezés által kijelölt térrészre vonatkozó hőmérsékletmező is. Az időkoordináta jelenlétében a hőmérsékletmező tranziens, időben változó jellegü, instacionárius. Időkoordináta hiányában állandósult (stacionárius) hőmérsékletmezőről beszélünk, ilyenkor a fenti (1) összefüggés az alábbi

$$
T=T(x, y, z)
$$

összefüggésre módosul.

\section{Szerszámgépek jellemző melegedési görbéi}

A hő terjedése a berendezésen található, illetve környezeti hőforrásokból indul el. A folyamat során, a hőmérsékletmező időbeli változása mellett, folyamatosan melegszenek a különböző gépegységek. A termikus egyensúlyra felírt összefüggések segítségével határozhatjuk meg a melegedési görbéket, vagyis az instacionárius hőmérséklet-idő diagramokat, amelyek megmutatják, hogy a vizsgált tartomány bizonyos pontjai hogyan érik el a termikus egyensúlyi állapotot. A valóságos melegedési görbék jelentős mértékben eltérhetnek az elméletitől, amint az az alábbi ábrán is megfigyelhető, amely egy felújított és friss kenőanyaggal ellátott csapágyház melegedési görbéjét ábrázolja (1. ábra).

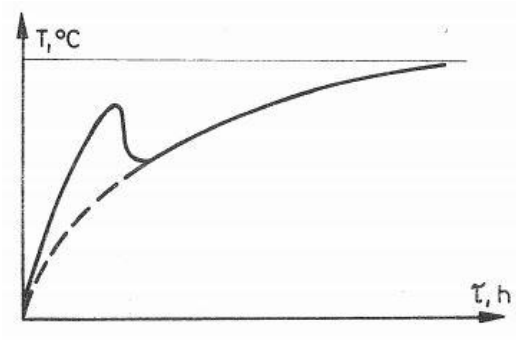

1. ábra. Elméleti és valós melegedési görbék összevetése [1]

\section{Melegedési folyamat szimulációs vizsgálata}

A melegedés folyamatát - bonyolultabb esetekben - parciális differenciálegyenlet-rendszer írja le. Ezek egzakt, zártformulás megoldása csak kivételes, egyszerübb esetekre ismert, így a mérnöki gyakorlat számára fontos eredmények elérése érdekében a numerikus matematika eszközeit használjuk. Elterjedten alkalmazzák a végeselem-módszert, amely a vizsgált tartományt véges számú elemre osztja fel, és elemen belüli közelítések segítségével állítja fel a keresett mezőmennyiségeket. Melegedésvizsgálat mellett alkalmazzuk berendezések szilárdságtani, dinamikai, rezgéstani és kinematika vizsgálatára. A számítások alapján egyes tulajdonságok optimális kialakítása is elvégezhető. Általa előre feltárhatók esetleges megmunkálás közbeni meghibásodások, illetve meghatározhatók a 
fejlesztési irányvonalak. Esetünkben segítségével összetett melegedési probléma megoldására teszünk kísérletet.

\subsection{A DMU 40 megmunkálóberendezés melegedésvizsgálata}

Ebben a fejezetben a vizsgálatba vont megmunkálóberendezés melegedésvizsgálatát mutatjuk be röviden. Megmunkálást imitáló peremfeltételek mellett végezzük szimulációs vizsgálatainkat. Először a berendezés 3D-s geometriai modelljét állítottuk elő, majd a marószerszám, az alkatrész, és számos egyéb peremfeltétel - hőterhelések, hőmérsékleti előírások, hőátadásra vonatkozó paraméterek, megmunkálási hőmérséklet és teljesítmény, hőforrások hőteljesítménye - hatását is figyelembe véve állítjuk elő a szimulációs modellt. Az alábbi ábrák jelenítik meg a valós struktúrát és a szimulációs modellt (2. ábra).
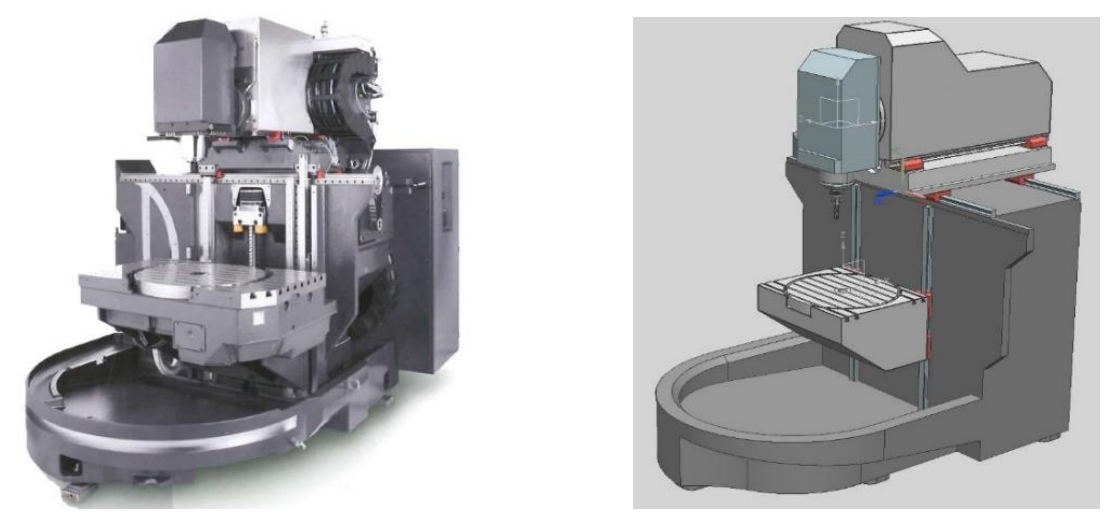

2. ábra. A vizsgálatba vont struktúra és annak geometriai modellje [2]

Viszonylag egyszerü marási folyamatot tételezünk fel szimulációs vizsgálataink során, melyhez WIDIA Warimill 4777 szerszámot alkalmazunk az alábbi megmunkálási és geometriai paraméterek mellett: szerszámátmérő $D_{1}=20 \mathrm{~mm}$, vágósebesség $v_{c}=150 \frac{\mathrm{m}}{\mathrm{min}}$, fogásmélység és előtolás $a_{p}=2 \mathrm{~mm} ; a_{e}=10 \mathrm{~mm}$. A szimulációhoz alkalmazott szerszám és munkadarab geometriát az alábbi ábrák mutatják (3. ábra).

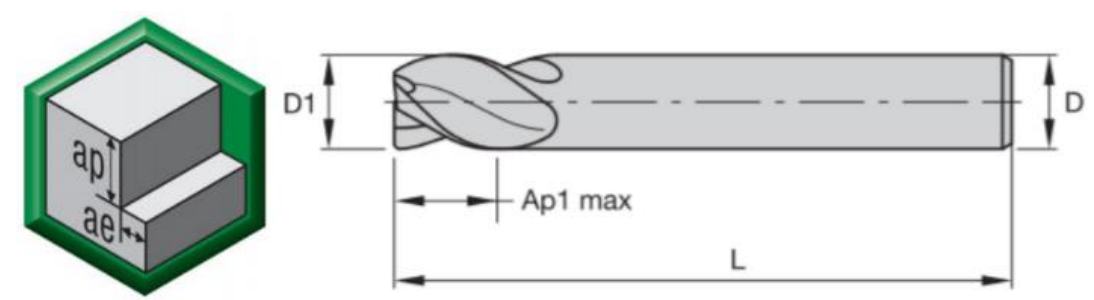

3. ábra. A szerszám és a munkadarab geometriája [3]

\subsection{A melegedés-szimuláció eredményei}

A számításokhoz előállítottuk a szimulációs modellt, melynek során a modellhez rendeltük a korábban említett anyagjellemzőket és peremfeltételeket. Szimulációs vizsgálatainkhoz az ANSYS szoftvercso- 
mag egyes moduljait használtuk. Előállítottuk a 3D-s geometria végeselem-hálóját, és ezt követően - a beépített algoritmus segítségével - előállítottuk a hőmérsékletmezőt, ez alapján a hőfeszültségmezőt és alakváltozásokat, végül pedig a méretváltozási jellemzőket. A mechanikai jellemzőket csatolt hőszilárdságtani analízis segítségével határoztuk meg.

Az alábbi, szimulációs diagramból kiolvasható, hogy a hőmérsékletmező maximális értéke közvetlenül a munkadarab és a marószerszám közös érintkezési felületein jelenik meg. E mellett a főorsó és más nagypontosságú egységek is jelentős hőterhelést szenvednek el. Az alábbi 4. ábra bal oldali diagramja a szerszámmegfogó környezetének hőeloszlását mutatja színskálán feltüntetve a várható hőmérséklettartományokat.

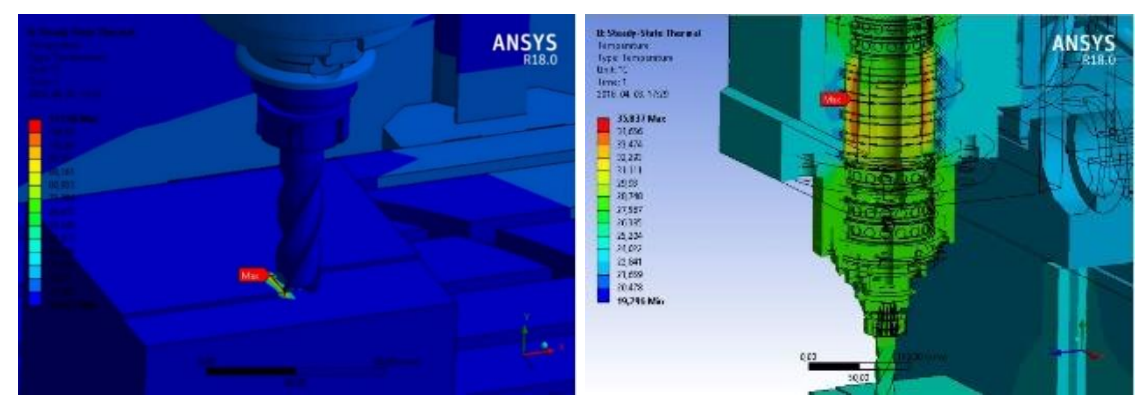

4. ábra. A marási folyamat során elöálló hömérsékletmezö

A hőmérsékleteloszlás mellett a mechanikai feszültségmezőt is meghatároztuk (5. ábra). Látható, hogy jelentős mértékủ feszültség ébred a szerszám-munkadarab érintkezésénél. Ez szintén a szerszámélettartam csökkenését és a megmunkálás pontatlanságát okozhatja. Az alakváltozási és az elmozdulásmezők is ismertté váltak. A munkadarab egészében homogén alakváltozási mezőt mutat, egységes $60 \mu \mathrm{m}$-es elmozdulást minden irány mentén. Ez a fajta alakváltozási mező két szempontból is kedvezö, egyrészt nyíró deformációk nem lépnek fel, tehát nincs szögtorzulás, másrészt pedig - az előzőből következően - a hosszirányú alak- és méretváltozások szoftveres algoritmussal könnyen kompenzálhatók.

Közvetlen kompenzáció segítségével - miközben szenzorok segítségével rögzítjük a hőmérsékletmezőt és a deformációkat - a CNC-vezérlésen keresztül módosul a korábban programozott szerszámpálya. Közvetett kompenzáció során a szimulációs modell alapján nyert adatok segítségével - szintén a vezérlésen keresztül - módosíthatjuk az éppen aktuális szerszámkoordinátákat. A fenti kompenzációs eljárások segítségével a hődeformációkból eredő megmunkálási pontosságok csökkenthetők nagy mértékben.
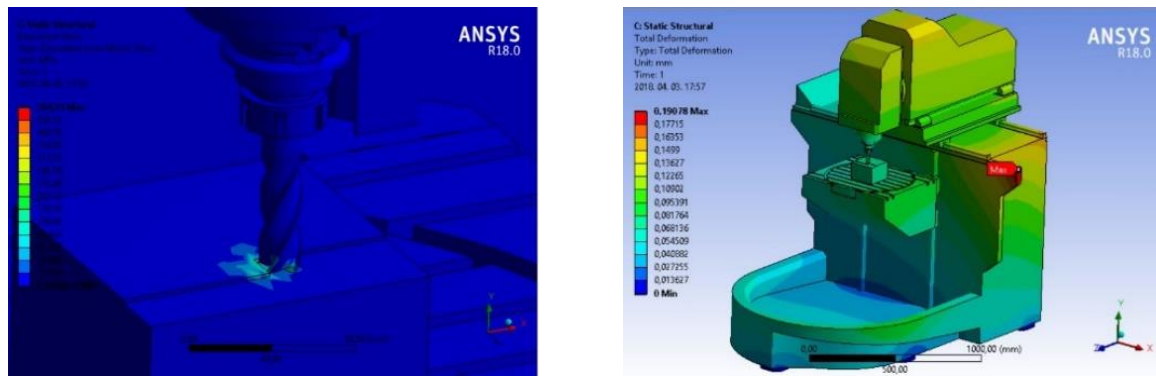

5. ábra. A marási folyamat során elöálló feszültségmezö 
A fenti ábrákból az is kitünik, hogy a szimulációhoz felhasznált geometriai modell csak a leglényegesebb építőelemeket használja, tehát viszonylag egyszerü geometriát használtunk. A geometriai modell bonyolultsága a számítási idővel függ össze: bonyolultabb geometria növelt számítókapacitást és időt igényel, így a modell optimális geometriájának megválasztása nem kerülhető el.

Érzékenységvizsgálatot is végeztünk a TCP-re (Tool Center Point) vonatkozóan: különböző megmunkálási paraméterek mellett számoltuk ki a vizsgált pont melegedési görbéjét. Ennek során feltételeztük, hogy a főorsó fordulatszáma időben változik (6. ábra bal felső diagramja), majd ezt bemeneti függvényként alkalmazva, különböző fordulatszámoknál határoztuk meg a vizsgált pont pillanatnyi hőmérsékletét, és kaptuk eredményül a 6 . ábra jobb felső görbéjét. Végül ezek alapján meghatároztuk a TCP axiális és radiális irányú elmozdulásfüggvényét. E görbék alapján megítélhető a marási folyamat hődeformációs hatása. Képet kaphatunk a hőforrások hatásáról, akárcsak a tervezési folyamat irányának helyességéről.

A 6. ábra a TCP melegedés hatására bekövetkező termikus és deformációs viselkedését mutatja.
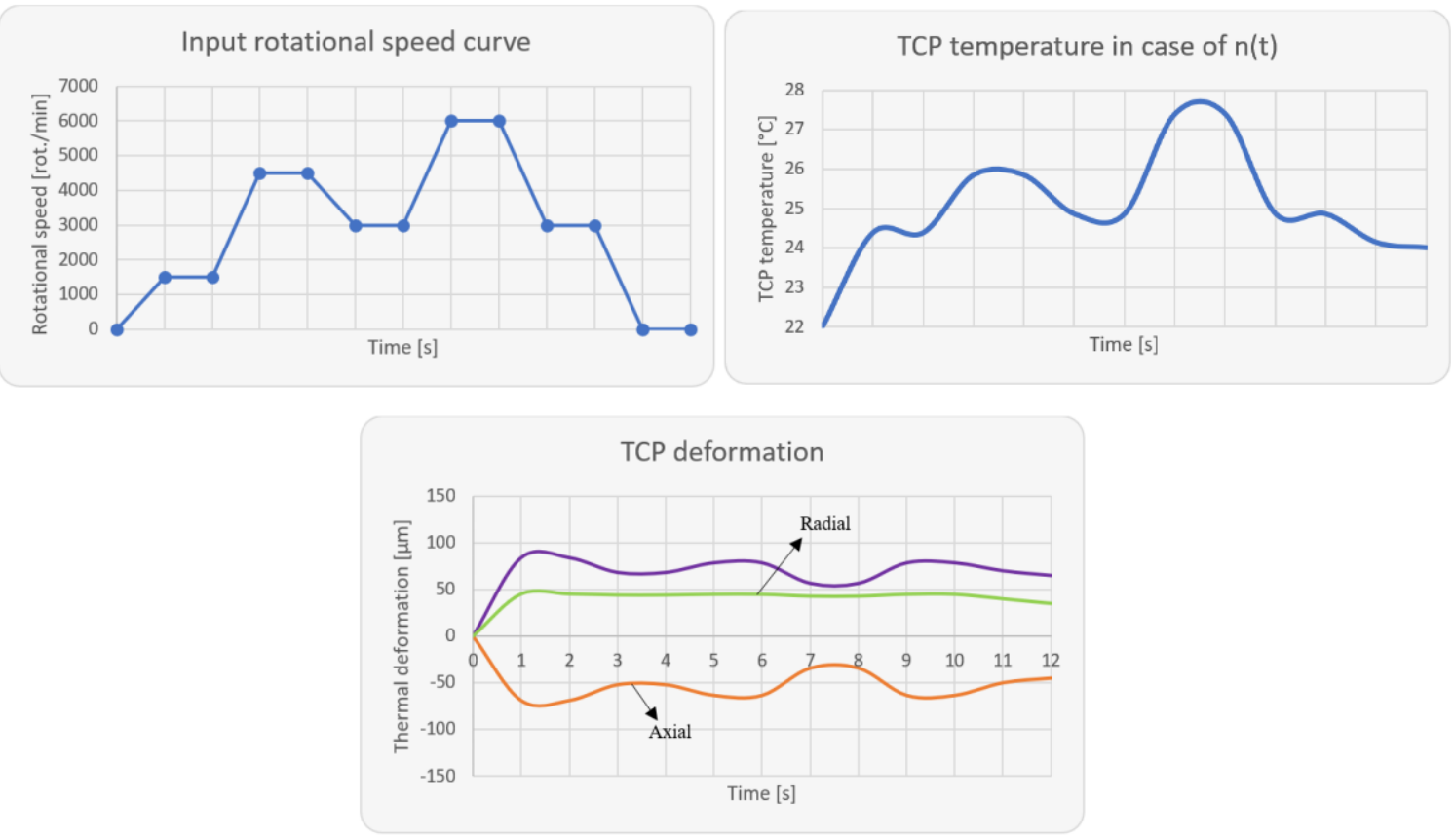

6. ábra. A TCP elmozdulása höterhelés hatására

\section{5. Összefoglalás}

Cikkünkben egy 5-tengelyes CNC fúró-maró megmunkálóközpont müködés közbeni melegedésvizsgálatát végeztük el szimulációs környezetben. Elsőként a hőmérsékletmezőt, és egyes elemek melegedési görbéit állítottuk elő. Ezt követően a végeselem-módszert alkalmaztuk a szimulációs környezet megteremtésére, majd meghatároztuk a hőmérsékletmezőt, és ez alapján a hődeformációkat és a hőfeszültségeket. A szimulációs eredmények alapján meghatároztuk a programozott pont (TCP) hődeformációk hatására bekövetkező elmozdulásait, amely az indirekt hőkompenzációs eljárások alapját képezi. 
Megjegyezzük, hogy a szimulációs környezeten elvégzett szimulációs vizsgálat kiemelt jelentőséggel bír egy berendezés tervezésének korai fázisában, hiszen eredményei alapján dönthetünk az eddigi konstrukciós irányvonal helyességéről, esetleg annak módosításáról. A végeselem-módszer hasznos szimulációs környezetet biztosít berendezések melegedésvizsgálatához, hiszen segítségével - ellentétben egy hőkamerás vizsgálattal - nem csak a felszíni, hanem tartomány belső pontjaiban fellépő hőmérsékleteloszlás is feltárható.

\section{Köszönetnyilvánítás}

A cikkben ismertetett kutató munka az EFOP-3.6.1-16-2016-00011 jelü „Fiatalodó és Megújuló Egyetem - Innovatív Tudásváros - a Miskolci Egyetem intelligens szakosodást szolgáló intézményi fejlesztése" projekt részeként - a Széchenyi 2020 keretében - az Európai Unió támogatásával, az Európai Szociális Alap társfinanszírozásával valósul meg.

\section{Irodalom}

[1] Baráti, A.: Szerszámgép-vizsgálatok, Műszaki Könyvkiadó, Budapest, 1988.

[2] https://en.dmgmori.com/

[3] https://www.widia.com/en/about-us.html 